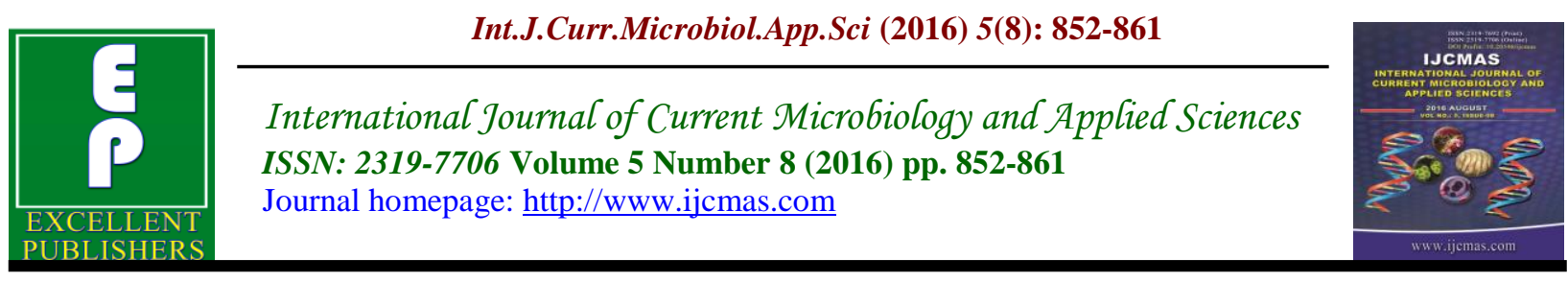

Original Research Article

http://dx.doi.org/10.20546/ijcmas.2016.508.096

\title{
Water Quality Characteristics of Vembanoor Wetland, Kanniyakumari District, Tamil Nadu, India
}

\author{
P. Priyatharsini ${ }^{1}$ and B. Dhanalakshmi ${ }^{2}{ }^{*}$ \\ ${ }^{1}$ Research scholar, PG \& Research Department of Zoology, Nirmala College for Women, India \\ ${ }^{2}$ Assistant Professor, PG \& Research Department of Zoology, Nirmala College for Women, India \\ *Corresponding author
}

\section{Keywords}

Wetland, Fresh

water, Physical

parameters,

chemical

parameters,

Eutrophication.

\section{Article Info}

Accepted:

28 July 2016

Available Online:

10 August 2016

\section{A B S T R A C T}

Wetlands are the planets most important fresh water resources which provide innumerable benefits for survival of life on earth. The aim of the current study was to gain a thorough knowledge on the status of the Vembanoor wetland with respect to seasonal variation in physico-chemical parameters (Colour, Temperature, Electrical conductivity, TDS, Turbidity, Transparency, pH, Alkalinity, Total hardness, Dissolved oxygen, Carbon dioxide, and Biological oxygen demand)during2013-2014. The methods employed for analysis of water samples were standard methods recommended by APHA (2005);WHO (2010); BIS(1991); ISI (1991) and ICMR (1975). The obtained values were compared with standard value limits. The result of the present study reveals that water quality parameters like $(\mathrm{pH}$, Total dissolved solids, Total hardness, Transparancy) are with in pre maximum permissible limits BIS and ISI and other parameters (Turbitity) showed some slight variations. In general with the above results of the present study revealed that though the wetland is oligotrophic, due to severe environmental impact it exhibits some characters of eutrophication. So a day is not far off, this wetland may disappear due to human greed, over exploitation and pollution in Kanniyakumari district.

\section{Introduction}

In present scenario fresh water resource in and around Kanniyakumari district are becoming deteriorated day by day at very faster rate due to unplanned urbanization, rapid industrialization, over pollution and indiscriminate use of artificial chemicals and varied pollution in aquatic environments leading to deterioration of water quality and depletion of aquatic macro fauna (fish). Vembanoor wetland, one of the major wetland of Kanyakumari district, surrounded by majestic hills, fringed with coconut trees and paddy lands lies between $8 \circ 10$ ' 54 ' N latitude and $77 \circ 22$ ' 33" E longitude in the southern tip of Tamil Nadu. This wetland has an average depth of $12-13 \mathrm{~m}$ with the surface area of the lake fully covered by floating and rooted vegetation. This wetland is located in and around human habitation. So the activities of resident surrounding the lake like bathing, cleaning utensils, washing 


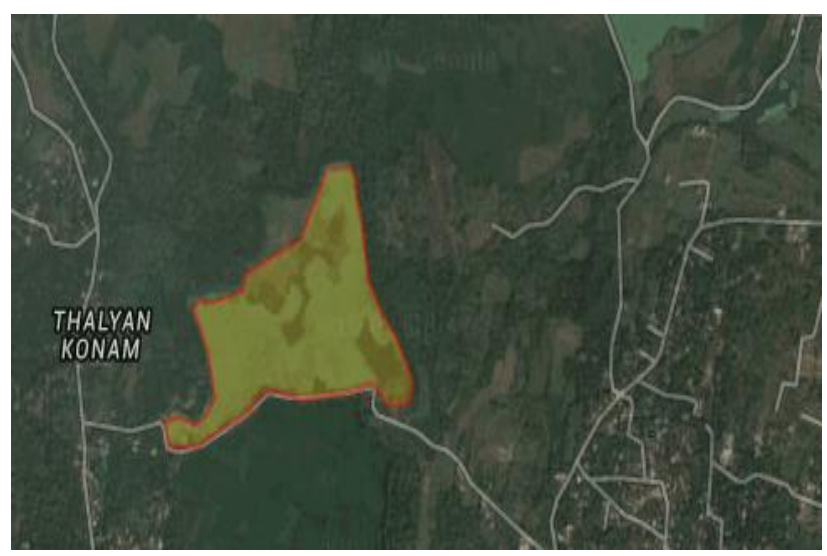

clothes, animals, vehicles idol immersions have subjected to a strong biotic pressure all along the periphery leading into a eutrophic stage (Gopal Goswami et al., (2010); Chinnaiah et al. (2011); Ra ullah et al.,(2012); PriyankaYadav et al., (2013); ShivaniShirke et al., (2014); Kistan, (2015). It also receives huge amount of untreated sewage, solid garbage's, domestic waste, resulting in the form of algal bloom and weed infestation. So in order in order to preserve aesthetic look of this Vembanoor lake which quench the thirst of village people in and around this wetland of Kanyakumari district and also do the asses the water suitability for human being and cattle consumption an attempt has been made to analysis thephysico-chemical characteristics of this sub-urban Vembanoor wetland during 2013- 2014.

\section{Materials and Methods}

The physicochemical characteristic of water is an important determinant of the aquatic system which is greatly influenced by general composition of water. Present investigation was carried out to study the physicochemical parameters of three seasons namely summer, monsoon andwinter. Three sampling stations (S-I, S-II, S-III) were selected for the present study on the basis of, nature and degree of pollution load being added to this wetland.

\section{Collection of water samples}

The water samples for the present study were collected at a monthly interval for a period of nine months from August 2013 to May 2014. Samples were collected every month from the surface of the wetland at $9.00 \mathrm{am}-10.00 \mathrm{am}$ in order to maintain uniformity. Water samples were collected from the selected stations in sterilized screw capped polyethylene bottles of one liters capacity and analyzed in laboratory for their physicochemical parameters. The collected samples were transported to the laboratory within $24 \mathrm{hrs}$ for analyzing various physicochemical parameters. For each sampling events colour, temperature, $\mathrm{pH}$, dissolved oxygen and transparency were monitored at the sampling sites, while other parameters were analyzed in the laboratory by adopting the procedures outlined by standard methods of APHA (2005); WHO (2010); BIS (1991); ISI (1991) and ICMR (1975).

\section{Results and Discussion}

Pollution caused by plethora of human activities primarily affects physicochemical, nutrient characteristics of water leading to destruction of community disrupting delicate food webs by deteriorating wetland ecosystem. The physicochemical parameters are considered as the important principles in the identification of the nature, quality and type of the water for any aquatic ecosystem. Seasonal variations of the Vembanoor lake physical parameters as per season are presented in (Table-1and 2)

During the study period at all the selected sites the colour of the water was noted to have different colours. The colour was noted brown at S-Iof the water was observed as it was being used as fishing ground and lot of human intervenes and at S-II it was 
observed to be black due to the mixing of effluents and other by product wastes from small idol making industries and paper boards made toy industries and the colour was noted brown at S-I due to the presence of algae and aquatic plants like Azolla and ferns. The odour of Vembanoor wetland water during the study period at S-I, S-II and S-II gave off algal odour, foul smell and fish odour thought the study period.

Temperature is basically an important factor for its effect on certain chemical and biological reactions taking place in water and in organisms that inhabits in aquatic media (Delirce, 1992). During the present study the maximum temperature recorded was $30.8^{\circ} \mathrm{Cat}$ site-I $31.2^{\circ} \mathrm{C}$, at site-II and $29.3^{\circ} \mathrm{C}$ at site III during summer and minimum temperature noted was $18.5^{\circ} \mathrm{C}$ at site I, $18.6^{\circ} \mathrm{C}$ at site II, and $18.1^{\circ} \mathrm{C}$ at site III during the winter period (Table-1). During summer the high water temperature may be due to reduction in water level and high solar radiation while low temperature was recorded in winter may be due to short day period (Bagade and Belagali, (2010); Pawar and Pandarkar, 2011). Temperature of water may not be as important as in pure water because of the wide range of temperature tolerance in aquatic life, but in polluted water temperature can have profound effects on dissolved oxygen and biological oxygen demand. Similar kind of observation with similar trends while working on different water bodies was reported by (Dwivediand Pandey, (2002); Singh and Mathur, (2005); Shinde and Deshmukh (2008); Ra ullah Khan et al., (2012); El Badaoui et al., (2015).

Electrical conductivity is an indirect measure of the water depends on the nature of water and concentration of salt. The minimum electrical conductivity recorded at S-I, S-II and S-III was $0.89 \mu \mathrm{mho} / \mathrm{cm}$ and
$1.07 \mu \mathrm{mho} / \mathrm{cm}$ and $0.49 \mu \mathrm{mho} / \mathrm{cm}$ during winter season and the maximum electrical conductivity was $1.05 \mu \mathrm{mho} / \mathrm{cm}$ at $\mathrm{S}-\mathrm{I}$; $1.12 \mu \mathrm{mho} / \mathrm{cm}$ at $\mathrm{S}$-II and $0.69 \mu \mathrm{mho} / \mathrm{cm}$ at S-III during summer. Maximum electrical conductivity was recorded during summer followed by monsoon at all stations while minimum electrical conductivity was recorded in winter (Table-1). Similar trend of electrical conductivity results were recorded by several workers like Mahima Chaurasia and Pandey, (2007); ShrmaRiddhi et al., (2011); Hulyal and Kaliwal, (2011); Priyankayadav et al., (2013); Alexander Singh et al., (2013). Seasonal variation in the conductivity may be due increase concentration of salts because of discharge of effluent and organic matter into this wetland lake.

Total dissolved solids indicate the general nature of the quality or salinity. Total dissolved solids analysis has great implications in the control of biological and physical waste water treatment processes. During the present study the total dissolved solids of water at site $-\mathrm{I}$ ranged between $1248 \mathrm{mg} / \mathrm{l}$ to $1022 \mathrm{mg} / 1,1258 \mathrm{mg} / 1-1006 \mathrm{mg} / \mathrm{l}$ at site - II and $11055 \mathrm{mg} / \mathrm{l}-1100 \mathrm{mg} / \mathrm{l}$ at site -III (Table-2). At all the selected study station the maximum amount of total solids was recorded during monsoon and minimum during winter. The total dissolved solids values were maximum during monsoon which may be due to leaching of soil and silt and followed by summer season due to low rate of evaporation and silt deposition and comparatively low during winter season due to less inlet of water. The increased level of total dissolved solids caused the ecological imbalance in the aquatic system by affecting the light penetration and turbidity of the water. Vembanoor wetland water body exhibited high values of total dissolved solids which are caused by the addition of huge quantities of sewage. Similar findings 
have been reported by Rao et al., (2003), Kirubavathy et al., (2005), Garg et al., (2006); Shiddamallayya and Prathima, (2008); Mohamed Toufeek and Korium (2009); Narasimmha and Benarjee (2013).

Transparency is a characteristic of water that varies with the combined effect of colour and turbidity. Minimum transparency of water ranged from 9 to $17 \mathrm{~cm}$ (S-III); 14 to $18 \mathrm{~cm}(\mathrm{~S}-\mathrm{II})$ and 12-to $19 \mathrm{~cm}$ at $(\mathrm{S}-\mathrm{I})$. The maximum transparency recorded $(30 \mathrm{~cm}$, $35 \mathrm{~cm}$ and $24 \mathrm{~cm}$ ) at S-I, S-II and S-III (Table-2). The clarity of natural body of water is an important determinant of its condition and productivity. During the study period transparency values were minimum during summer season due to high planktonic population followed by monsoon season because of increase in the suspended matter brought in through surface run off. The maximum transparency was recorded in winter season attributed to the sedimentation of suspended matter (Chaurasia and Adoni, (1985); Sinha et al., (2002); Kadam et al., (2007); Shah and Pandit, (2012).

In the present study water turbidity values ranged from $15.54 \mathrm{NTU}-30.54 \mathrm{NTU}$ at station -I, 11.79NTU -48NTU at S-II and $11.4 \mathrm{NTU}$ to $17.86 \mathrm{NTU}$ at station-III. The minimum values recorded were $15.54 \mathrm{NTU}$, $11.79 \mathrm{NTU}$ and $11.4 \mathrm{NTU}$ during winter season and while maximum values 30.54NTU, 48NTU, 17.86NTU were recorded during the monsoon season (Table2). During the present study maximum turbidity was noted during monsoon season which may be due to incoming of slit, clay and other suspended particles from local dumping, construction sites, runoff from surrounding regions which would have contributed considerable amount of allochanthous materials rendering the water most turbid, while minimum during winter and summer season due to settlement of suspended and dissolved solids, slit, clay. The present study result was in similar to Medudhula Thirupahi et al., (2012).

\section{Chemical parameters}

The results of mean values of chemical parameters of the selected three sampling Sites I, II, III of study area were represented in (Table 3-4)

The $\mathrm{pH}$ is measure of the intensity of acidity or alkalinity and measures the concentration of hydrogen ions in water. It has no direct adverse effect on health, however, a low value, below 4.0 will produce sour taste and higher value above 8.5 shows alkaline taste. A $\mathrm{pH}$ range of $6.5-8.5$ is normally acceptable as per guidelines suggested By ISI, 1991; ICMR, 1975; WHO, 2005; BSI, 1991. The maximum $\mathrm{pH}$ was recorded during summer (8.0- S-I; 8.2; -S-II;7.8=SIII) followed by monsoon(S-I-7.8; S-II-8.1; S-III-7.6) in all the stations(Table-3). During the winter season the minimum value recorded were 7.5, 7.9, 6.7 at S-I, S-II, S-III. The recorded $\mathrm{pH}$ valuesin the water samples analyzed were shown to be neutral to alkaline in all the selected study sites (Table-3). The alkaline nature of water may be due to presence of carbonates and bicarbonates of alkali and alkaline earth metals (Rana and Palria, 1998).According to AjitKalwale et al.,(2012) it was observed the $\mathrm{pH}$ of the normally remains higher in summer and in monsoon season followed by winter which was in accordance to the present result.The maximum are due to decreased decomposition rate owing to reduced microbial activity and increased decomposition rate leading to acidification and lowered $\mathrm{pH}$ (Chetanaand Somashekar, (1997); Similar study has been reported by Patel and Tiwari, (1998); Archana Gupte and NisarShikh (2013). 
The total alkalinity ranged from $233 \mathrm{mg} / \mathrm{l}$ $340 \mathrm{mg} / \mathrm{l}$ (S-I), 277mg/l- 415 (S-II) and 218-308 (S-III). Among the selected stations site - II recorded higher alkalinity followed by site- III and site-I. Presence of uncombined carbon dioxide, organic acids, tannic acids ,mineral acids, hydrolyzing salts and salts of strong and weak bases are responsible for higher value at site II entering from small scale industries, agro based industries, mixing of hospital wastes, domestic sewages from early by inhabitant areas(Table-3). Similar kind of observation off reported by JacklinJemi and Regini Balasingh, (2011); Mariapushpam et al., (2013). Higher alkalinity indicated in site-II is highly productive when compared to other two sites, site-I 340mg/l and $308 \mathrm{mg} / \mathrm{l}$ siteIII. Higher values at site II are due to the presence of carbonates, bicarbonates and hydroxide ions. However the prescribed limit for total alkalinity is $120 \mathrm{mg} / \mathrm{l}$. All the values were observed among the selected stations were above the permissible limits.

Hardness is an important parameter in the detection of water pollution due to presence of calcium and magnesium ions. The total hardness of water is an important consideration in determining the suitability of water for domestic and industrial uses. Total hardness recorded in all the selected stations was found to be maximum (210mg/l, 283mg/l 203mg/l) during the summer seasons and minimum values (188mg/l, 195mg/l and 105mg/l) during winter seasons (Table-3). Hardness of water increases due to washing of clothes, agricultural runoff and automobile cleaning Prathap Singh and ReginiBalasingh, (2011).A high concentration of hardness may be due to leaching from the soils or due to high background concentration of the water. Increase in hardness can also be attributed to the decrease in water volume and increase in the rate of evaporation at high temperature. According to WHO,2010 permissible limit for total harness of water is $150 \mathrm{mg} / 1$ and (ISI, 1991) desirable limit is 300mg/l. Hujare, (2008), PatilShilpa et al. (2012); Hulyal and Kaliwal (2011); Priyanka Yadav et al., (2012); Alexander singh and Bijen Meitei (2013); et al., (2016), reported total hardness was high during summer followed by rainy season and minimum during winter season.

Minimum dissolved oxygen value $(6.7,6.9$, $6.4 \mathrm{mg} / \mathrm{l})$ at S-I, S-II and S-III was recorded during summer season due to increase in temperature. Maximum $(6.7 \mathrm{mg} / 1,9.5 \mathrm{mg} / 1$, $6.6 \mathrm{mg} / \mathrm{l})$ was recorded during monsoon may be due to cooling of lake water by rain and low temperature (Table-4). Similar observation was also recorded at wular lake, Kashmir by Rumysakhaliq et al., (2012) and Garg et al., (2010) in Ramsagar reservoir, India. Dissolved oxygen is one of the most important parameters which reflect physical and biological processes prevailing in waters. Its correlation with water body gives direct and indirect information e.g. bacterial activity, photosynthesis, availability of nutrients, stratification etc. (PremlataVikal, (2009). Dissolved oxygen presents its important to maintain the higher forms of biological life like fish in the water. Dissolved oxygen can be removed from the water by discharges of the oxygen demanding wastes, which other inorganic reluctant like hydrogen sulphide, ammonia, ferrous, nitrate and other oxidable substances tends to decrease dissolved oxygen in water. The low dissolved oxygen concentration observed during summer could be ascribed to the higher salinity of the water and high temperature. According to Patra et al., (2010); Narasimha Ramulu and Benarje, (2013); Alexander singhsingh and Bijen Meitei, (2013) maximum and minimum value of oxygen were recorded during monsoon season followed by summer season. 
Carbon dioxide is essential for photosynthesis and its concentration affects the phytoplankton, and its productivity. Although carbon dioxide is a minor component of air it is abundant in water because of its solubility which is 30 times more than that of oxygen, and the amount of carbon dioxide in water usually shows an inverse relationship with oxygen (Radhika et al., (2004). The concentration of carbon dioxide during the present study period ranged from $4.2 \mathrm{mg} / \mathrm{l}-5.2 \mathrm{mg} / \mathrm{l}$ at $\mathrm{S}-\mathrm{I} 7.5 \mathrm{mg} / \mathrm{l}$ $-9.3 \mathrm{mg} / \mathrm{l}$ at $\mathrm{S}-\mathrm{II}$ and $4.2 \mathrm{mg} / \mathrm{l}-5.0 \mathrm{mg} / \mathrm{l}$ at S-III (Table-4). During the study period high concentration of carbon dioxide was recorded during summer and lower concentration during winter season. High concentration of carbon dioxide during the warmer period may be due to the decomposition of organic matter, utilizing dissolved oxygen and liberating carbon dioxide. Excess of its get disassociated in to carbonic acid. Radika et al., (2004) reported an annual variation in carbon dioxide parameter in waterbodies of Kerala. Jaklinjemi and ReginiBalasingh, (2011); Ubharhande and sonawane, (2012) in their study reported that maximum amount of carbondioxide was recorded during summer and minimum concentration in winter.
BOD at S-I was fluctuating between 9.9$12.8 \mathrm{mg} / \mathrm{l}$, at $\mathrm{S}$-II it was recorded 10.35 $15.5 \mathrm{mg} / \mathrm{l}$ and $8.2-12.05 \mathrm{mg} / \mathrm{l}$ at S-III. Among the stations the maximum biological oxygen demand was observed in S-II followed by SIII and S-I. Biological oxygen demand was is the amount of oxygen required by the living organisms engaged in the utilization and ultimate destruction or stabilization of organic water (Hawkes, (1993). It is very important indicator of the pollution status of a water body. Maximum BOD was observed in the selected site I,II and III during summer season and minimum during winter(Table-4).According to WHO, 2004 the permissible limit of biological oxygen demand was 3 to $4 \mathrm{mg} / \mathrm{l}$. High biological oxygen demand values at site II may be due to pollutants biodegradable of organic origin. Biological oxygen demand gives a quantitative index of the degradable organic substances in water and is used as a measure of waste strength. The low BOD value in all samples showed good sanitary condition water. Seasonal variation in BOD values, with the higher values during summer months followed by rainy and winter months was recorded(Kumar and Sharma, (2005); Mohamed (2005);Mahima Chaurasia and pandey 2007; Kiran, (2010).

Table.1 Data on the seasonal variations of physical parameters of Vembanoor wetland

\begin{tabular}{|c|c|c|c|c|c|c|c|c|c|}
\hline \multirow[t]{3}{*}{ Seasons } & \multicolumn{9}{|c|}{ Physical Parameters } \\
\hline & \multicolumn{3}{|c|}{$\begin{array}{c}\text { Colour } \\
(\text { HZ) }\end{array}$} & \multicolumn{3}{|c|}{$\begin{array}{c}\text { Temperature } \\
\left({ }^{\circ} \mathrm{C}\right)\end{array}$} & \multicolumn{3}{|c|}{$\begin{array}{c}\begin{array}{c}\text { Electrical conductivity } \\
(\mu \mathrm{mho} / \mathrm{cm})\end{array} \\
\end{array}$} \\
\hline & S-I & S-II & S-III & S-I & S-II & S-III & S-I & S-II & S-III \\
\hline Summer & Brown & Black & Green & 30.8 & 31.2 & 29.3 & 1.05 & 1.12 & 0.69 \\
\hline Monsoon & Brown & Black & Green & 29.7 & 29.9 & 28.5 & 0.99 & 1.11 & 0.66 \\
\hline Winter & Brown & Black & Green & 18.5 & 18.6 & 18.1 & 0.89 & 1.07 & 0.49 \\
\hline
\end{tabular}

$*$ All the values are means of triplicate observations $(\mathrm{N}=3)$

* SI- station I; S-II- station -II S-III- station-III 
Table.2 Data on the seasonal variations of physical parameters of Vembanoor wetland

\begin{tabular}{|c|c|c|c|c|c|c|c|c|c|}
\hline \multirow{3}{*}{ Seasons } & \multicolumn{4}{|c|}{ Physical Parameters } \\
\cline { 2 - 10 } & \multicolumn{3}{|c|}{$\begin{array}{c}\text { Total dissolved solids } \\
\text { (mg/l) }\end{array}$} & \multicolumn{3}{c|}{$\begin{array}{c}\text { Transparency } \\
\text { (cm) }\end{array}$} & \multicolumn{3}{|c|}{$\begin{array}{c}\text { Turbidity } \\
\text { (mg/l) }\end{array}$} \\
\cline { 2 - 10 } & S-I & S-II & S-III & S-I & S-II & S-III & S-I & S-II & S-III \\
\hline Summer & 1258 & 1058 & 1010 & 12 & 14 & 9 & 24.64 & 48.00 & 11.79 \\
\hline Monsoon & 1258 & 1055 & 1048 & 14 & 30 & 12 & 30.54 & 48 & 17.86 \\
\hline Winter & 1002 & 1006 & 10000 & 20 & 19 & 17 & 11.79 & 15.54 & 11.40 \\
\hline
\end{tabular}

*All the values are means of triplicate observations $(\mathrm{N}=3)$

* SI- station I; S-II- station -II S-III- station-III

Table.3 Data on the seasonal variations of chemical parameters of Vembanoor wetland

\begin{tabular}{|c|c|c|c|c|c|c|c|c|c|}
\hline \multirow[t]{3}{*}{ Seasons } & \multicolumn{9}{|c|}{ CHEMICAL PARAMETERS } \\
\hline & \multicolumn{3}{|c|}{$\mathbf{p H}$} & \multicolumn{3}{|c|}{ Alkalinity (mg/l) } & \multicolumn{3}{|c|}{ Total hardness (mg/l) } \\
\hline & S-I & S-II & S-III & S-I & S-II & S-III & S-I & S-II & S-III \\
\hline Summer & 8.0 & 8.2 & 7.8 & 340 & 415 & 308 & 203 & 235 & 104 \\
\hline Monsoon & 7.8 & 8.1 & 7.6 & 233 & 277 & 218 & 200 & 235 & 104 \\
\hline Winter & 7.5 & 7.9 & 6.7 & 306 & 384 & 294 & 188 & 195 & 102 \\
\hline
\end{tabular}

*All the values are means of triplicate observations $(\mathrm{N}=3)$

* SI- station I; S-II- station -II S-III- station-III

Table.4 Data on the seasonal variations of chemical parameters of Vembanoor wetland

\begin{tabular}{|c|c|c|c|c|c|c|c|c|c|}
\hline \multirow{2}{*}{ Seasons } & \multicolumn{9}{|c|}{ Chemical Parameters } \\
\cline { 2 - 10 } & \multicolumn{3}{|c|}{$\begin{array}{c}\text { Dissolved oxygen } \\
\text { (mg/l) }\end{array}$} & \multicolumn{2}{c|}{$\begin{array}{c}\text { Dissolved carbon } \\
\text { dioxide (mg/l) }\end{array}$} & \multicolumn{2}{c|}{$\begin{array}{c}\text { Biological oxygen demand } \\
\text { (mg/l) }\end{array}$} \\
\hline & S-I & S-II & S-III & S-I & S-II & S-III & S-I & S-II & S-III \\
\hline Summer & 6.7 & 6.9 & 6.4 & 5.2 & 9.3 & 5.2 & 12.8 & 15.5 & 12.5 \\
\hline Monsoon & 6.7 & 9.5 & 6.6 & 4.9 & 8.9 & 4.5 & 11.65 & 13.25 & 11.09 \\
\hline Winter & 7.9 & 8.6 & 6.3 & 4.2 & 7.5 & 3.3 & 9.9 & 10.35 & 8.2 \\
\hline
\end{tabular}

*All the values are means of triplicate observations $(\mathrm{N}=3)$

* SI- station I; S-II- station -II S-III- station-III

The reason of high content of BOD in summer months could be due to the fact that several microbes accelerated their metabolic activities with concentrated amount of organic matter discharged due to human activities, and hence required more amount of oxygen.

In conclusion, the investigation for going carried out at Vembanoor wetland indicated that the physico-chemical parameters of the water body are partial (or) wholly associated with the season and the water level in the lake. Currently the status of Vembanoor wetland is considered to be less polluted. Vembanoor wetland is precious to all the residents and aquatic life. So, it is suggested that immediate measures are necessary to be indicated to avoid further contamination of this wetland due to anthropological 
activities. The preservation of wetland aquatic resources in and around urban cites is for sustaining, human health and wellbeing is a paramount concern worldwide. And these wetlands though fit for drinking and irrigation purpose yet it need new to minimize some contaminations. So environmental awareness among the local people of that area to maintain the wetland water and their quality and purity levels. Should be created and stringent measures should be adopted to preserve the status of the Vembanoor lakes.

\section{Acknowledgements}

The Authors highly acknowledge the support and help form the PG and Research Department of Zoology, Nirmala college foe women, Coimbatore for providing lab facilities.

\section{References}

Ajit, M., Kalwale1, Padmakar, A., Savale. 2012. Determination of PhysicoChemical Parameters of DeoliBhorus Dam water. Pelagia Research Library, Adv. Appl. Sci. Res., 3(1): 273-279.

Alexander singh, N. SanamachaMeetei and. Bijen Meitei, L. 2013. Seasonal variation of some physico- chemical characteristics of tree Major RiversinImphal, Manipur: A comparative Evaluation. Curr. World Environ., Vol- 8(1):93-102.

APHA. 2005. Standard methods for the examination of water and waste ter. $21^{\text {st }}$ Edn., Washington, D.c.

Archana Gupte and NisarShikh. 2013. Seasonal variations in physicochemical parameters and primary productivity of Shelar lake Bhiwandi, Thane, Maharastra. Universal J. Environ. Res. Technol., Vol- 3(4): 523-530.

Badaoui, El. Amar, N.Y. Joaqum-Justo, C.
Djahed, B. Ammar, H. Benosman, R. Thomé J.P. 2015. Assessment of Pollution in SidiM'HamedBenali Lake Algeria) Based on Bioindicators and Physicochemical Parameters, Iranica J. Energy and Environ., 6(4): 308-315.

Chaurasia, S.k., Adoni, A.d. 1985. Zooplankton dynamics in a shallow Eutrophic lake Proc. Nat. Symp. Pure Appl. Limnology Bot. Soc. Sagar. Vol32:30-39.

Chinnaiah, B., Madhu, V., Ramesh Babu, M. 2013. Physico-chemical characterstics of khajana and darmasagar lakes, in Adilabad, AndhraPradesh, India. Int. J. Pharmacy \& Life Sci., Vol 2(4):674676.

Dwivedi, B.K. and G.C Pandey. 2002. Physico chemical factotes and algal diversity of ponds, (GirijaKund and Maqubara Pond), Faizabad. Poll. RS, 21: 361-370.

Garg, R.K., Saksena, D.N. Rao, R.J. 2006. Assessment of physico- chemical water quality of Harsi Reservoir, District Gwalior, Madhya Pradesh, J. Ecophysiol. Occupational Health, Vol-6:33-40.

Gopal GoswamiSudin Pal and DebnathPalit 2010. Studies on the physicochemical characteristics, Macrobyte Diversity and their economic prospect in RajamataDighi: A wetland in cooch Behar District, West Bengal, India. Ne BIO. Vol-1(3).

Hujare, M.S. 2008. Seasonal variation of physico-chemical parameters in the perennial tank of talsandeMaharastra, Ecotoxicol. Environ. Monitoring, Vol18(3):233-242.

Hulyal, S.B. and Kaliwal, B.B. 2011. Seasonal variation in physico chemical characteristics of AlmattiResrvior of Bijapur District, Kanataka State, IJEP, Vol-1:58-67. 
Jacklin Jemi, R. and G.S. Regini Balasingh. 2011. Studies on physico-chemical characteristics of freshwater temple ponds in Kanyakumari District South Tamilnadu. Int. J. Geol. Earth and Environ. Sci., 1(1): 59-62.

Javaid Ahmad Shah and Ashok, K., Pandit. 2012. Physico-chemical characteristics of water in wular lake -a ramsar site in kashmirhimalaya. Int. J. Geol. Earth and Environ. Sci., Vol. 2(2) MayAugust, pp.257-26.

Kadam, M.S., Pampatwar D.V., Mali, R.P. 2007. Seasonal variations in different physico chemical characteristics in Mosoli reservoir Of Parbhani district, Maharastra, J. Aquatic Biol., Vol22(10):110-112.

Kiran, B.R. 2010. Physico chemical characteristics of fish ponds of Bhadra project at Karnataka. Rasayan $J$. Chem., Vol-3(4):671-676.

Kirubavathy, A.K, Binukumari. Mariamma, N. Rajammal, T. 2005. Assessment of water quality of Orathupalayam Reservoir, Erode District, Tamil Nadu. J. Ecophysiol. Occupational Health, Vol-5:35-51.

Mahima Chaurasia and pandey, G.C. 2007. Study of physico- chemical characteristics of some water ponds of AyodhyaFaizabab, IJEP, Vol- 27(11): 1019-1023.

Maria Pushpam, P., Umayoru Bhagan, V., Kumaraswamy, A. 2013. Comparative Analysis of Physicochemical Parameters of Two Famous Temple Tanks in Kanyakumari District, S.India. Int. J. Latest Trends in Engi. Technol., Vol. 2 Issue 2

Medudhula Thirupathaiah, Ch., Samatha, ChinthaSammaiah. 2012. Analysis of water quality using physico-chemical parameters in lower manair reservoir of Karimnagar district, Andhra Pradesh. Int. J. Environ. Sci.,
Volume3, No 1, 172-180.

Mohamed, A.F., Toufeek and Mostafa, A., Korium.

Physicochemical Characteristics of Water Quality in Lake Nasser Water. Global J. Environ. Res., 3(3): 141-148.

Mohamed, H., Abdo. 2005. Physico chemical characteristics of $\mathrm{ABU} \mathrm{Za}$ BAAL ponds, Egypt. Egyptian $J$. Aquatic Res., Vol.31 No, 2.1-15.

Narasimha Ramulu, K., and Benarjee, G. 2013. Physico-chemical factors influenced plankton biodiversity and fish abundance-a case study of Nagaram tank of Warangal, Andhra pradesh. Int. J. Life Sc. Bt \& Pharm., Vol. 2, No. 2.

Patil Shilpa, G., Chonde Sonal, G., Jadhav Aasawari, S., and Raut Prakash, D. 2012. Impact of physico chemical characteristics of shivaji University lakes on phytoplankton Communities, Kolhapur India. Research J. Recent Sci., Vol -1(2), 50-60.

Patra, A.P., Patra, J.K., Mahapatra, N.K. Das, S. and Swain, G.C. 2010. Seasonal variation in physico chemical parameters of chilka lake after opening of new mouth near Gabakunda, Orissa, India.

Pawar, B.A. and Pandarkar, A.K. 2011. Studies on water quality of Kelewadilake in relation to PisicultureMaharastra, Uttar Pradesh. J. Zool., Vol-31(1):35-41.

Prathap Singh, R. and Regini Balasingh, G.S., Limnological Studies of Kodaikanal Lake Dindugal District), in Special Reference to Phytoplankton Diversity, Indian J. Fundamental and Appl. Life Sci., Vol. 13 ), pp.112-118.

Priyankayadav, V.K. Yadav, A.K. Yadav, and P.K. Khare. 2013. Physicochemical characteristic of a fresh water pond of Orai, U.P., Central India. Octa journal of Biosciences. 
Vol-1(2): 177-184.

Ra ulla, M., Khan, Milind, J. Jadhav and Rustad. 2012. Physico chemical analysis of Trivani lakewater ofAmaravath District in MS India, Biosci. Discovery, Vol-3(10):64-66.

Rana, B.C. and Palria, S. 1988. Assessment, Evaluation and Abatement studies of a polluted river Bandi Rajasthan. In Ecology and Pollution of Indian Rivers Ed. R.K. Trivedy) pp. 345-359, Ashish Publishing House, New Delhi.

Rao, K.D.S., Ramakrishnaiah, M. Karthikayen, M. Sukuaran, P.K. 2003. Limnology and fish yield enhancement Reservior Cauvery River system) J. Inland Fisheries society of India.

Rumysa Khaliq, Sharique, A., Ali, Tariq Zafar, Mohd. Farooq, Bilal, A. and Pinky Kaur. Physico- chemical Status of Wular Lake in Kashmir. Journal of chemical. Biol. Physical Sci., Vol3(1): 631-636.

Sakare and Joshi, 2003. Environmental aspects of lake water and its quality management.

Shiddamallayya, P.N. and Prathima, M. 2008. Impact of domestic sewage on fresh water body. J. Environ. Biol, Vol-29(3): 303-8.
Shinde, A.H., Deshmukh. 2008. Seasonal changes in physico-chemical characteristics of Zirapurwadi Lake. World Lake Conference.

Shivani Shirke, Sneha Phand, Kruthika, D.L., Sesha Sai, Ch. Venkatesh Reddy, M. Chaithanya Sudha. 2014. Plankton diversity and water quality assessment of two lakes in vellore district tamilnadu, india. with special reference to planktonic indicators. Int. J. Adv. Technol. Engi. Sci., Volume No.02, Issue No. 09,186-194.

Singh, R.P. and Mathur. 2005. Investigation of variations in physico chemical characteristics of a fresh water reservoir of Ajmar city, Rajasthan. Ind. J. Env. SCi., Vol-9:57-61.

Sinha, M.P, Kumar, R. Mishra S.K. and Choudhuri, A.K. 2002. Eco taxonomyand biomonitoring of lake for conservation and management. Biotic Profile In: Ecology and conservation of lakes, Reservoirs and Rivers Edited. Vol-II 248-289.

Ubharhande, S.B. and sonawane S.R 2012. Study of fresh water fish fauna and water quality at Paintaakli dam from Buldhanadistricet, M.S) India. $J$. Experimental Sci., Vol 3(7):04-08.

\section{How to cite this article:}

Priyatharsini, P., and Dhanalakshmi, B. 2016. Water Quality Characteristics of Vembanoor Wetland, Kanniyakumari District, Tamil Nadu, India. Int.J.Curr.Microbiol.App.Sci. 5(8): 852861. doi: http://dx.doi.org/10.20546/ijcmas.2016.508.096 